\title{
Correlation of BRAF and NRAS mutation status with outcome, site of distant metastasis and response to chemotherapy in metastatic melanoma
}

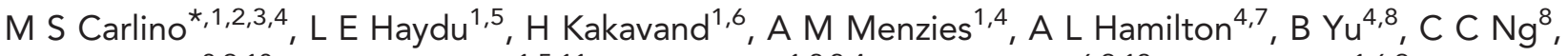
W A Cooper $8,9,10$, J F Thompson ${ }^{1,5,11}$, R F Kefford ${ }^{1,2,3,4}$, S A O'Toole ${ }^{6,9,12}$, R A Scolyer ${ }^{1,6,9}$ and G V Long ${ }^{1,4}$ ${ }^{1}$ Melanoma Institute Australia, Sydney, New South Wales, Australia; ${ }^{2}$ Westmead Institute for Cancer Research, University of Sydney at Westmead Millennium Institute, Westmead, New South Wales, Australia; ${ }^{3}$ Department of Medical Oncology, Crown Princess Mary Cancer Centre, Westmead Hospital, Westmead, New South Wales, Australia; ${ }^{4}$ Discipline of Medicine, Sydney Medical School, The University of Sydney, Sydney, New South Wales, Australia; ${ }^{5}$ Discipline of Surgery, Sydney Medical School, The University of Sydney, Sydney, New South Wales, Australia; ${ }^{6}$ Discipline of Pathology, Sydney Medical School, The University of Sydney, Sydney, New South Wales, Australia; ' Department of Medical Oncology, Royal Prince Alfred Hospital, Camperdown, New South Wales, Australia; ${ }^{8}$ Department of Medical Genomics, Royal Prince Alfred Hospital, Camperdown, New South Wales, Australia; ${ }^{9}$ Department of Tissue Pathology and Diagnostic Oncology, Royal Prince Alfred Hospital, Camperdown, New South Wales, Australia; ${ }^{10}$ School of Medicine, University of Western Sydney, Sydney, NSW, Australia; ${ }^{11}$ Department of Melanoma and Surgical Oncology, Royal Prince Alfred Hospital, Camperdown, New South Wales, Australia and ${ }^{12}$ The Kinghorn Cancer Centre and Cancer Program Garvan Institute of Medical Research, Victoria Street, Darlinghurst, New South Wales, Australia
\end{abstract}

Background: The prognostic significance of BRAF and NRAS mutations in metastatic melanoma patients remains uncertain, with several studies reporting conflicting results, often biased by the inclusion of patients treated with BRAF and MEK (MAPK) inhibitors. We therefore interrogated a historical cohort of patients free of the confounding influence of MAPK inhibitor therapy.

Methods: Patients with available archival tissue first diagnosed with metastatic melanoma between 2002 and 2006 were analysed. Mutational analysis was performed using the OncoCarta Panel. Patient characteristics, treatment outcome and survival were correlated with BRAF/NRAS mutation status.

Results: In 193 patients, 92 (48\%) melanomas were BRAF-mutant, 39 (20\%) were NRAS-mutant and 62 (32\%) were wild-type for BRAF/NRAS mutations (wt). There was no difference in response to chemotherapy based on mutation status (35-37\%). The distant disease-free interval (DDFI) was significantly shorter in patients with wt melanoma (27.9 months vs 35.1 for BRAF and 49.1 for NRAS) although this was not significant in multivariate analysis. Survival from stage IV melanoma diagnosis was not significantly different based on mutation status. The DDFI was significantly shorter in patients with $\mathrm{BRAF}^{\mathrm{V} 600 \mathrm{~K} / \mathrm{R}}$ versus $\mathrm{BRAF}{ }^{\mathrm{V} 600 \mathrm{E}}$ melanoma in univariate and multivariate analyses.

Conclusions: BRAF and NRAS mutation status does not influence survival in metastatic melanoma.

*Correspondence: Dr MS Carlino; E-mail: matteo.carlino@sydney.edu.au

Revised 8 April 2014; accepted 30 April 2014; published online 10 June 2014

(c) 2014 Cancer Research UK. All rights reserved 0007-0920/14 
Activating mutations in the oncogenes BRAF or NRAS occur in approximately 40 and $20 \%$ of melanomas, respectively, and result in constitutive activation of the mitogen-activated kinase (MAPK) cell signalling pathway (Davies et al, 2002; Platz et al, 2008). Small molecule inhibitors of mutant BRAF and the downstream kinase MEK (MAPK inhibitors) have transformed the management of BRAF-mutant metastatic melanoma and improved overall survival (OS) compared with standard chemotherapy in patients with $B R A F^{\mathrm{V} 600}$ mutant metastatic melanoma (Chapman et al, 2011; Flaherty et al, 2012; Hauschild et al, 2012). Similarly, although to a lesser extent, single agent MEK inhibition has shown activity in NRAS-mutant metastatic melanoma (Falchook et al, 2012; Ascierto et al, 2013), with a phase III trial currently underway (NCT01763164).

The presence of a BRAF mutation in metastatic colorectal cancer is associated with a shorter OS compared with KRAS mutant or RAS/RAF wild-type disease (Van Cutsem et al, 2011; Yokota et al, 2011; Toland et al, 2012). Similarly BRAF mutations are associated with an increased risk of recurrence in papillary thyroid cancer (Elisei et al, 2012; Prescott et al, 2012; Fernandez et al, 2013). The prognostic significance of a BRAF mutation in metastatic melanoma is less clear. Recent analysis of survival in metastatic melanoma patients were performed when BRAF and MEK inhibitors were available and some patients included received these therapies (Long et al, 2011; Jakob et al, 2012), making comparisons between the BRAF-mutant and wild-type populations difficult. One study examining BRAF status only (Long et al, 2011) reported no difference in survival from stage IV diagnosis between patients with $B R A F$-mutant and wild-type metastatic melanoma; however, when the analysis was limited to patients with $B R A F$ mutant melanoma who did not receive a MAPK inhibitor, a significantly shorter survival in BRAF-mutant patients was observed. It is unclear if this difference in survival was due to differences in the biology of BRAF-mutant versus wild-type melanoma or a selection bias due to the non-random selection of $B R A F$-mutant patients for entry into the early phase clinical trials of MAPK inhibitors. Another study examining BRAF and NRAS status reported that NRAS-mutant melanoma was associated with the poorest survival (Jakob et al, 2012). However, an earlier study found that NRAS-mutant melanoma was associated with improved survival compared with BRAF-mutant or BRAF/NRAS wild-type disease (Ugurel et al, 2007).

This uncertainty regarding the prognostic significance of $B R A F$ and NRAS mutations in metastatic melanoma led us to perform a retrospective analysis in a cohort of patients with advanced melanoma who were treated before the availability of MAPK inhibitors. We sought to correlate BRAF and NRAS mutation status with clinicopathologic characteristics, response to chemotherapy and survival, as well as to determine the frequency of other oncogenic mutations in metastatic melanoma.

\section{MATERIALS AND METHODS}

Patient selection and data collection. This study was undertaken at the Melanoma Institute Australia (MIA) in conjunction with Westmead Hospital and Royal Prince Alfred Hospital with human ethics review committee approval (Protocol No. X11-0023 and HREC/11/RPAH/32). All patients consented to data collection and enrolment in the melanoma research database (MRD). Patients with newly diagnosed metastatic melanoma (stage IV) managed at MIA between 2002 and 2006 with available archival paraffinembedded melanoma tissue suitable for DNA extraction were included. To exclude the effect of survivor bias, which may occur at a quaternary referral cancer centre, patients not seen at the MIA before or within 4 weeks of developing metastatic melanoma were excluded.
Patient demographics, primary tumour characteristics (date of primary diagnosis, Breslow thickness, ulceration, mitotic rate, ulceration, $\mathrm{N}$ stage), clinical details at the time of diagnosis of stage IV melanoma ( $M$ stage, serum lactate dehydrogenase (LDH), organ involvement), and data regarding progress after development of stage IV disease (development of brain metastasis, treatment with systemic therapy and response to chemotherapy) were collected from the MRD and further review of the clinical record. For patients with more than one primary melanoma, the 'culprit' primary deemed responsible for subsequent metastatic disease was designated using a previously described algorithm (Murali et al, 2012; Mann et al, 2013). Chemotherapy included dacarbazine, temzolomide, fotumustine, combined carboplatin and paclitaxel or experimental combinations including these agents. Immunotherapy included vaccines and experimental agents. No patient was treated with IL-2, ipilimumab, class 1 BRAF inhibitors or MEK inhibitors. Treatment benefit was determined prospectively by the clinician, with either disease stability or a reduction in tumour burden during treatment considered as a beneficial response.

Tumour samples and molecular testing. Distant metastatic samples were preferentially sampled over lymph nodes or primaries where available. DNA was extracted from one core sample taken from one archival formalin-fixed, paraffin-embedded (FFPE) tissue block of melanoma for each patient in the study. DNA was extracted using NucleoSpin FFPE DNA Kit (Macherey Nagel, Düren, Germany) according to the manufacturer's instruction with an overnight proteinase digestion. The quality and quantity of the extracted DNA was assessed using NanoDrop ND-1000 Spectrophotometer. A minimum of $500 \mathrm{ng}$ of DNA was required for successful mutational analysis. All samples were successfully amplified and analysed for 238 variant targets in a 24 multiplex polymerase chain reactions (PCR) using the OncoCarta Panel v1.0 Kit including 19 tumour-related genes such as $B R A F$, NRAS, KIT and PIK3CA (http://bioscience.sequenom.com/oncocarta-panel). The genotypes were called based on the matrixassisted laser desorption ionisation-time of flight mass spectrometry (MALDI-TOF) technology on the Sequenom MassArray platform. Specifically, the key targeted mutational hotspots in this assay were G464R/V/E, G466R, F468C, G469A/E/R/S/V, D594V/G, F595L, G596R, L597Q/R/S/V, T599I, V600E/K/R/L, K601N/E for $B R A F$ and G12V/A/D/C/R/S, G13V/A/D/C/R/S, A18T, Q61L/R/P/ $\mathrm{H} / \mathrm{E} / \mathrm{H} / \mathrm{K}$ for $N R A S$.

Statistical methods. Clinical and pathologic features were tested for associations with BRAF or NRAS mutation status using simple cross-tabulations, independent samples $t$-test, Fisher's exact test, Pearson c2, and/or the Mann-Whitney $U$ test. The distant diseasefree interval (DDFI) was measured from the date of culprit primary melanoma diagnosis to diagnosis of distant metastatic disease. Overall survival was calculated from the date of diagnosis of stage IV melanoma to last follow-up (censored) or death from melanoma (event). Univariate survival analyses was carried out using the Kaplan-Meier method together with the log-rank (Mantel-Cox) test to calculate statistical significance. Univariate hazard ratios (HRs), 95\% confidence intervals (95\% CI), and corresponding $P$-values were obtained using Cox regression. A Bonferroni correction was applied to all $P$-values resulting from the univariate DDFI and survival analyses to adjust for multiple comparisons. Multivariate survival analyses were conducted with Cox proportional hazards method. The proportionality assumption was inspected visually for each categorical covariate. A two-tailed $P$-value of less than 0.05 was considered statistically significant. All analyses were prespecified and carried out with the IBM SPSS Statistic 19.0 software package. 


\section{RESULTS}

Patients, tumour samples and mutation frequency. Between 2002 and 2006, 322 patients with a new diagnosis of metastatic melanoma were seen at MIA. Nine patients were excluded because they were first diagnosed with metastatic disease more than 4 weeks before their first consultation at MIA. Archival FFPE melanoma tissue sufficient for DNA analysis was available in 193 of the 313 eligible patients. Mutations were identified in tumours from $140(73 \%)$ patients, and $10(5 \%)$ patients had more than one mutation. BRAF mutations were detected in 92 patients (48\%), and NRAS mutations in 39 patients (20\%) (Table 1). No targeted mutations were identified in 53 patients $(27 \%)$. Of the patients with BRAF mutations, 65 (71\%) were V600E and 18 (20\%) were V600K. Of the patients with an NRAS mutation, 33 (85\%) were substitutions for glutamine at position $61(\mathrm{Q} 61 \mathrm{H} / \mathrm{K} / \mathrm{L} / \mathrm{R})$ and 6 (15\%) were substitutions for glycine at amino acids 12 (G12C/D) or $13(\mathrm{G} 13 \mathrm{C} / \mathrm{S})$. No tumours harboured both an NRAS and BRAF mutation. Twenty-three mutations, in $19(10 \%)$ patients, were detected in genes other than BRAF/NRAS; the most common were mutations in $\operatorname{KIT}(n=7,4 \%)$ or PIK3CA $(n=7,4 \%)$ (Supplementary Table S1).

Correlations with clinical features (Supplementary Table S2) and survival analyses were not performed based on mutations other than BRAF or NRAS genes because of the small numbers and the heterogeneity of the mutation types. Subsequent analyses were based on a patient's tumour BRAF and NRAS status, and three cohorts were compared and analysed: BRAF-mutant $(n=92)$; NRAS-mutant $(n=39)$; and those in whom no targeted mutation was found in BRAF or NRAS (wt, $n=62$ ).

Patient demographics and clinicopathologic features of primary melanoma based on BRAF and NRAS mutation status. Patients with $B R A F$-mutant melanoma were significantly younger at diagnosis of the culprit primary melanoma than those with wt melanoma (Median 53 versus 59 years, $P=0.002$ ) (Table 2). Acral lentiginous and demoplastic melanoma subtypes appeared to be more common in the wt cohort; however, the small numbers in each subtype precluded statistical analysis (Table 2). There was no

\begin{tabular}{|c|c|c|}
\hline Mutation & Number of patients (\%) & \\
\hline BRAF & $92(48)$ & $\%$ Of BRAF \\
\hline V600E & 65 (34) & 71 \\
\hline V600K & $18(9)$ & 20 \\
\hline V600R & $2(1)$ & 2 \\
\hline G469R & $2(1)$ & 2 \\
\hline K601E & $3(2)$ & 3 \\
\hline K601N & $1(0.5)$ & 1 \\
\hline L597Q & $1(0.5)$ & 1 \\
\hline NRAS & $39(20)$ & $\%$ Of NRAS \\
\hline $\mathrm{Q} 61 \mathrm{H}$ & $1(0.5)$ & 3 \\
\hline Q61K & $13(7)$ & 33 \\
\hline Q61L & $4(2)$ & 10 \\
\hline Q61R & $15(8)$ & 38 \\
\hline G12C & $1(0.5)$ & 3 \\
\hline G12D & $3(2)$ & 8 \\
\hline G13C & $1(0.5)$ & 3 \\
\hline G13S & $1(0.5)$ & 3 \\
\hline
\end{tabular}

significant difference in Breslow thickness, mitotic rate, presence of ulceration and nodal status between the three cohorts at diagnosis of the culprit primary melanoma (Table 2).

Clinical characteristics and treatment received for stage IV melanoma. Patients with $B R A F$-mutant disease were significantly younger than those with wt at first diagnosis of stage IV melanoma (median age 56 versus 63 years, $P=0.03$ ) (Table 3 ). A higher proportion of patients with NRAS-mutant melanoma had M1c (anatomically defined) melanoma at first diagnosis of stage IV compared with patients with BRAF-mutant or wt melanoma (Table 3). Serum LDH at stage IV diagnosis was not associated with mutation status (Table 3 ). There was a trend to an increased incidence of liver and CNS metastasis at diagnosis of stage IV disease in patients with NRAS-mutant melanoma, although the risk of developing CNS metastasis at any time was similar between the three groups (40-45\%) (Table 3).

The number of patients who received systemic therapy, either chemotherapy or immunotherapy, was not different between the three cohorts (Table 3). There was no difference in clinicianassessed benefit from chemotherapy, (35-37\%) (Supplementary Table S3).

Distant disease-free interval and survival analysis. Although distant disease-free interval (DDFI) was significantly shorter in the wt cohort (27.9 months) compared with either the BRAF (35.1 months, $P=0.03$ ) or NRAS-mutant (median 49.1 months $(P=0.01)$ populations (Figure $1 \mathrm{~A})$, this difference did not remain significant in multivariate analysis when known prognostic factors for DDFI were included (Table 4). There was no difference in OS between the three cohorts from the time of diagnosis of stage IV melanoma (Figure 1B) or in OS from culprit primary (Supplementary Figure S1).

When analysed by $B R A F$ mutation genotype within the BRAFmutant cohort, patients with $B R A F^{\mathrm{V} 600 \mathrm{~K}}$ or $\mathrm{R}$ genotype melanoma had a significantly shorter DDFI ( $n=20$, median 22 months) than those with $B R A F^{\mathrm{V} 600 \mathrm{E}}(n=65$, median 45 months, $P=0.001)$ (Figure 1C); this difference remained significant in multivariate analysis (Table 5). There was no difference in OS from diagnosis of stage IV disease between the $B R A F^{\mathrm{V} 600 \mathrm{~K} / \mathrm{R}}$ and the BRAF ${ }^{\mathrm{V} 600 \mathrm{E}}$ patients (Figure 1D). There was a trend towards a shorter survival from culprit primary in patients with $B R A F^{\mathrm{V} 600 \mathrm{~K}}$ or $\mathrm{R}$ compared with $B R A F^{\mathrm{V} 600 \mathrm{E}}$ genotype melanoma (Supplementary Figure S2). The small numbers $(n=7)$ of non-V600 BRAF mutations precluded further analysis of this subgroup.

There was a trend towards a shorter DDFI in patients who had an exon 2 (codon 61, $n=23$ ) compared with those with an exon 1 (codon 12/13, $n=6$ ) NRAS mutation (Supplementary Figure S3, $P=0.091)$. There was no difference in OS between the NRAS genotypes from diagnosis of stage IV disease $(P=0.66)$.

\section{DISCUSSION}

This is one of the largest studies to examine the prognostic significance of $B R A F$ and NRAS mutation status in patients with metastatic melanoma, diagnosed and treated before the availability of BRAF and MEK inhibitors. In contrast to other large studies, our survival analyses were not confounded by the availability BRAF and MEK inhibitors (Long et al, 2011; Jakob et al, 2012). Previous large studies in primary melanomas were not powered to examine survival, as only $10 \%$ of patients with early-stage melanoma develop metastatic disease (Maldonado et al, 2003; Chang et al, 2004; Houben et al, 2004; Shinozaki et al, 2004; Akslen et al, 2005), although one study found NRAS-mutant disease was associated with a poorer survival (Devitt et al, 2011a). NRAS mutations have also been found to be associated with fast growing primary melanomas (Nagore et al, 2013). In the metastatic 


\begin{tabular}{|c|c|c|c|c|c|c|c|c|c|}
\hline Feature & $N$ & Value & $\begin{array}{c}W T \\
N=62\end{array}$ & $\%$ & $\begin{array}{l}\text { NRAS, } \\
N=39\end{array}$ & $\%$ & $\begin{array}{l}\text { BRAF, } \\
N=92\end{array}$ & $\%$ & $\begin{array}{c}\text { Three group } \\
P \text {-value }\end{array}$ \\
\hline Age at first primary $\mathrm{Dx}$ & 171 & Median (Range) & $59(26-80)$ & - & $54(25-76)$ & - & $53(16-82)$ & - & $0.006^{\mathrm{a}}$ \\
\hline Breslow thickness (mm) & 170 & Median (Range) & $2.5(0.2-25)$ & - & $2.5(0.3-8.1)$ & - & $2.15(0.3-25)$ & - & $0.426^{\mathrm{a}}$ \\
\hline Mitotic rate $\left(\right.$ per $\mathrm{mm}^{2}$ ) & 139 & Median (Range) & $3(0-15)$ & - & $3(0-33)$ & - & $4(0-34)$ & - & $0.267^{a}$ \\
\hline Sex & 193 & $\begin{array}{l}\text { Male } \\
\text { Female }\end{array}$ & $\begin{array}{l}44 \\
18\end{array}$ & $\begin{array}{l}71 \\
29\end{array}$ & $\begin{array}{l}24 \\
15\end{array}$ & $\begin{array}{l}62 \\
38\end{array}$ & $\begin{array}{l}62 \\
30\end{array}$ & $\begin{array}{l}67 \\
33\end{array}$ & 0.616 \\
\hline Multiple primary & 193 & $\begin{array}{l}\text { No } \\
\text { Yes }\end{array}$ & $\begin{array}{l}52 \\
10\end{array}$ & $\begin{array}{l}84 \\
16\end{array}$ & $\begin{array}{r}35 \\
4\end{array}$ & $\begin{array}{l}90 \\
10\end{array}$ & $\begin{array}{l}82 \\
10\end{array}$ & $\begin{array}{l}89 \\
11\end{array}$ & 0.562 \\
\hline Primary site & 193 & $\begin{array}{l}\text { Cutaneous } \\
\text { Plantar surface of the foot } \\
\text { Toenail } \\
\text { Mucosal } \\
\text { Occult }\end{array}$ & $\begin{array}{r}48 \\
3 \\
2 \\
3 \\
6\end{array}$ & $\begin{array}{c}77 \\
5 \\
3 \\
5 \\
10\end{array}$ & $\begin{array}{r}31 \\
0 \\
0 \\
2 \\
6\end{array}$ & $\begin{array}{c}79 \\
0 \\
0 \\
5 \\
15\end{array}$ & $\begin{array}{r}78 \\
4 \\
0 \\
0 \\
10\end{array}$ & $\begin{array}{c}85 \\
4 \\
0 \\
0 \\
11\end{array}$ & $N A^{b}$ \\
\hline Melanoma subtype & 130 & $\begin{array}{l}\text { Acral lentiginous } \\
\text { Nodular melanomac }^{c} \\
\text { Superficial spreading }^{\text {Other }^{\text {d }}}\end{array}$ & $\begin{array}{r}4 \\
16 \\
6 \\
14\end{array}$ & $\begin{array}{l}10 \\
40 \\
15 \\
35\end{array}$ & $\begin{array}{r}1 \\
15 \\
3 \\
7\end{array}$ & $\begin{array}{c}4 \\
58 \\
11 \\
27\end{array}$ & $\begin{array}{r}2 \\
34 \\
5 \\
23\end{array}$ & $\begin{array}{c}3 \\
53 \\
8 \\
36\end{array}$ & $N A^{b}$ \\
\hline Ulceration & 136 & $\begin{array}{l}\text { Absent } \\
\text { Present }\end{array}$ & $\begin{array}{l}17 \\
26\end{array}$ & $\begin{array}{l}40 \\
60\end{array}$ & $\begin{array}{r}16 \\
9\end{array}$ & $\begin{array}{l}64 \\
36\end{array}$ & $\begin{array}{l}36 \\
32\end{array}$ & $\begin{array}{l}53 \\
47\end{array}$ & 0.132 \\
\hline $\mathrm{N}$ stage of culprit primary or occult melanoma & 193 & $\begin{array}{l}\text { N0 } \\
\text { N1a/b } \\
\text { N2a/b/c } \\
\text { N3 }\end{array}$ & $\begin{array}{r}50 \\
4 \\
7 \\
1\end{array}$ & $\begin{array}{c}81 \\
6 \\
12 \\
2\end{array}$ & $\begin{array}{r}29 \\
5 \\
4 \\
1\end{array}$ & $\begin{array}{c}74 \\
13 \\
11 \\
3\end{array}$ & $\begin{array}{r}62 \\
12 \\
11 \\
7\end{array}$ & $\begin{array}{c}67 \\
13 \\
12 \\
8\end{array}$ & $N A^{b}$ \\
\hline $\begin{array}{l}\text { Abbreviations: } \mathrm{Dx}=\text { diagnosis; } \mathrm{NA}=\text { not applicable; } \mathrm{W} \\
\mathrm{a}_{\text {KKruskal-Wallis independent samples test. }} \\
\mathrm{b}_{\text {Low expected cell frequency. }} \\
\boldsymbol{c}_{\text {Including superficial spreading with a nodular melano }} \\
\mathbf{d}_{\text {Lentigo maligna melanoma and desmoplastic. }}\end{array}$ & & & & & & & & & \\
\hline
\end{tabular}

melanoma population, the data regarding associations of melanoma genotype and survival are conflicting (Edlundh-Rose et al, 2006; Ugurel et al, 2007; Long et al, 2011; Brissy et al, 2012; Jakob et al, 2012; Ekedahl et al, 2013). One study showed that patients with NRAS-mutant tumours had an improved OS compared with those with BRAF-mutant or wt tumours (Ugurel et al, 2007), whereas another study suggested NRAS-mutant melanoma predicted a poorer OS from stage IV disease (Jakob et al, 2012). A further study found that the presence of either NRAS or BRAF mutations was associated with a poorer survival in the setting of metastatic disease (Houben et al, 2004). Our finding that mutation status is not prognostic in the setting of stage IV melanoma is in keeping with other studies before the availability of BRAF and MEK inhibitors (Chang et al, 2004; Edlundh-Rose et al, 2006). The data regarding the prognostic impact of mutation status in patients with stage III disease are similarly conflicting. Some studies found no prognostic impact of mutation status (Rutkowski et al, 2012) and others found an association between $B R A F$-mutant melanoma and poorer OS (Moreau et al, 2012; Mann et al, 2013). Although we found a significantly shorter DDFI in patients with wt disease, which has not been shown in prior studies that tested both $B R A F$ and NRAS mutations (Jakob et al, 2012), it was not significant in multivariate analysis suggesting important differences in prognostic variables in the culprit primary melanoma.

There are many possible reasons for the lack of consistent results regarding the prognostic impact of BRAF and NRAS mutation status in both early and advanced melanoma, including the mutation testing method, patient selection and geographic variations in the risk of specific melanoma mutations. Different mutation testing methodologies with different sensitivities and specificities were used in various studies. In contrast to our study, very few prior studies analysed for a comprehensive range of melanoma-associated BRAF and NRAS mutations. As an example, a subset of studies did not test for exon 1 (codon 12/13) NRAS mutations (Edlundh-Rose et al, 2006; Devitt et al, 2011a) whereas others limited survival analysis only to $B R A F$ substitutions for valine at codon 600 (Jakob et al, 2012). The OncoCarta assay is robust for FFPE samples and sensitive (detection limit of 10\%) for the targeted hotspots within BRAF and NRAS. Although this assay does not analyse the complete genes or exons of interest, it does include all the key melanoma-associated NRAS mutations in exons 1 and 2 and BRAF mutations in exons 11 and 15 (Greaves et al, 2012).

Patient selection varied substantially between studies, and may be the most important factor influencing the different results between them. Methods of patient selection include selection of consecutive patients (Long et al, 2011; Moreau et al, 2012), selecting patients from a clinical database (Jakob et al, 2012), or, as in this study, selecting patients on the basis of available tissue (Houben et al, 2004; Rutkowski et al, 2012; Mann et al, 2013). This study minimised other selection biases by including all patients seen within a defined time period and limited the effect of survival bias by excluding those referred to our clinical service more than 4 weeks after the first diagnosis of metastatic melanoma. Each method of patient selection is associated with potential biases; clinically accrued data sets are likely to enhance for survivors, particularly as initially testing was performed for entry onto clinical trials or access to novel therapies, with a consequent referral bias of healthier and fitter patients who are willing to travel for experimental treatments (Long et al, 2011; Jakob et al, 2012). Studies in which patients are selected based on available archival tissue may skew the population towards patients who have had 
Table 3. Stage IV clinical characteristics based on mutation status

\begin{tabular}{|c|c|c|c|c|c|c|c|c|c|}
\hline Feature & $N$ & Value & WT, $N=62$ & $\%$ & $\begin{array}{l}\text { NRAS, } \\
N=39\end{array}$ & $\%$ & BRAF, $N=92$ & $\%$ & $\begin{array}{c}\text { Three group } \\
P \text {-value }\end{array}$ \\
\hline Age & 193 & Median (Range) & $63(29-84)$ & - & 57 (29-78) & - & $56(17-85)$ & - & 0.096 \\
\hline DFI (months) & 171 & Median (Range) & $28(0-112)$ & - & $49(6-137)$ & - & $35(0-366)$ & - & $0.156^{a}$ \\
\hline Site of stage IV diagnosis & 193 & $\begin{array}{c}\text { Skin } \\
\text { Lung } \\
\text { Gl } \\
\text { Liver } \\
\text { Bone } \\
\text { Brain } \\
\text { Other }^{b}\end{array}$ & $\begin{array}{r}36 \\
41 \\
6 \\
21 \\
6 \\
8 \\
12\end{array}$ & $\begin{array}{l}58 \\
66 \\
10 \\
34 \\
10 \\
13 \\
19\end{array}$ & $\begin{array}{r}31 \\
26 \\
5 \\
18 \\
4 \\
8 \\
8\end{array}$ & $\begin{array}{l}79 \\
67 \\
13 \\
46 \\
10 \\
21 \\
21\end{array}$ & $\begin{array}{r}62 \\
47 \\
5 \\
24 \\
18 \\
16 \\
20\end{array}$ & $\begin{array}{c}67 \\
51 \\
5 \\
26 \\
20 \\
17 \\
22\end{array}$ & $\begin{array}{l}0.083 \\
0.099 \\
0.333 \\
0.079 \\
0.163 \\
0.581 \\
0.937\end{array}$ \\
\hline M stage & 169 & $\begin{array}{l}\text { M1a } \\
\text { M1b } \\
\text { M1c }\end{array}$ & $\begin{array}{r}1 \\
12 \\
42\end{array}$ & $\begin{array}{c}2 \\
22 \\
76\end{array}$ & $\begin{array}{r}1 \\
4 \\
31\end{array}$ & $\begin{array}{c}3 \\
11 \\
86\end{array}$ & $\begin{array}{r}11 \\
9 \\
58\end{array}$ & $\begin{array}{l}14 \\
12 \\
74\end{array}$ & 0.027 \\
\hline Number of metastatic sites & 193 & $\begin{array}{l}1 \\
2 \\
3 \\
4 \\
5\end{array}$ & $\begin{array}{r}22 \\
23 \\
7 \\
9 \\
1\end{array}$ & $\begin{array}{c}35 \\
37 \\
11 \\
15 \\
2\end{array}$ & $\begin{array}{r}8 \\
12 \\
10 \\
7 \\
2\end{array}$ & $\begin{array}{c}21 \\
31 \\
26 \\
18 \\
5\end{array}$ & $\begin{array}{r}33 \\
28 \\
23 \\
6 \\
2\end{array}$ & $\begin{array}{c}36 \\
30 \\
25 \\
7 \\
2\end{array}$ & $N A^{c}$ \\
\hline LDH & 134 & $\begin{array}{l}\text { Not elevated } \\
\text { Elevated }\end{array}$ & $\begin{array}{l}24 \\
21\end{array}$ & $\begin{array}{l}53 \\
47\end{array}$ & $\begin{array}{l}15 \\
13\end{array}$ & $\begin{array}{l}54 \\
46\end{array}$ & $\begin{array}{l}36 \\
25\end{array}$ & $\begin{array}{l}59 \\
41\end{array}$ & 0.872 \\
\hline ECOG PS & 171 & $\begin{array}{l}0 \\
1 \\
2\end{array}$ & $\begin{array}{r}39 \\
16 \\
3\end{array}$ & $\begin{array}{c}67 \\
28 \\
5\end{array}$ & $\begin{array}{r}20 \\
9 \\
5\end{array}$ & $\begin{array}{l}59 \\
26 \\
15\end{array}$ & $\begin{array}{r}48 \\
29 \\
2\end{array}$ & $\begin{array}{c}61 \\
37 \\
2\end{array}$ & 0.134 \\
\hline Brain metastases ever & 193 & $\begin{array}{l}\text { No } \\
\text { Yes }\end{array}$ & $\begin{array}{l}37 \\
25\end{array}$ & $\begin{array}{l}60 \\
40\end{array}$ & $\begin{array}{l}23 \\
16\end{array}$ & $\begin{array}{l}59 \\
41\end{array}$ & $\begin{array}{l}51 \\
41\end{array}$ & $\begin{array}{l}55 \\
45\end{array}$ & 0.854 \\
\hline Surgery & 191 & $\begin{array}{l}\text { No } \\
\text { Yes }\end{array}$ & $\begin{array}{l}27 \\
34\end{array}$ & $\begin{array}{l}44 \\
56\end{array}$ & $\begin{array}{l}17 \\
22\end{array}$ & $\begin{array}{l}44 \\
56\end{array}$ & $\begin{array}{l}28 \\
63\end{array}$ & $\begin{array}{l}31 \\
69\end{array}$ & 0.169 \\
\hline Chemotherapy & 183 & $\begin{array}{l}\text { No } \\
\text { Yes }\end{array}$ & $\begin{array}{l}20 \\
40\end{array}$ & $\begin{array}{l}33 \\
67\end{array}$ & $\begin{array}{l}15 \\
21\end{array}$ & $\begin{array}{l}42 \\
58\end{array}$ & $\begin{array}{l}32 \\
55\end{array}$ & $\begin{array}{l}37 \\
63\end{array}$ & 0.797 \\
\hline Immunotherapy & 188 & $\begin{array}{l}\text { No } \\
\text { Yes }\end{array}$ & $\begin{array}{r}57 \\
4 \\
\end{array}$ & $\begin{array}{c}93 \\
7\end{array}$ & $\begin{array}{r}35 \\
4 \\
\end{array}$ & $\begin{array}{l}90 \\
10 \\
\end{array}$ & $\begin{array}{l}72 \\
16 \\
\end{array}$ & $\begin{array}{l}82 \\
18 \\
\end{array}$ & 0.134 \\
\hline $\begin{array}{l}\text { Abbreviations: ECOG PS = Easte } \\
\text { a }_{\text {Kruskal-Wallis independent sar }} \\
\text { b }_{\text {Spleen, pancreas, adrenal, ome }} \\
{ }_{\text {L }} \text { Low expected cell frequency. }\end{array}$ & $\begin{array}{l}\text { oope } \\
\text { s test } \\
\text { n, thy }\end{array}$ & $\begin{array}{l}\text { e Oncology Group } \\
\text { kidney, stomach, }\end{array}$ & $\begin{array}{l}\text { mance status; D } \\
\text { gallbladder. }\end{array}$ & & terval; LDH & & ehydrogenase; $\mathrm{N}$ & & le; $W T=$ wild-type \\
\hline
\end{tabular}

surgery for stage III or IV disease, who may represent a separate prognostic group with different mutational profiles. Geographical variations may also explain the differences in the impact of mutation status on prognosis. $B R A F^{V 600 K}$ mutation is associated with chronic UV damage (Menzies et al, 2012) and varies by geography (Houben et al, 2004; Edlundh-Rose et al, 2006; Ugurel et al, 2007; Long et al, 2011; Amanuel et al, 2012; Jakob et al, 2012; Menzies et al, 2012).

Little is known about other genetic or epigenetic factors, which can occur concurrently with BRAF and NRAS mutations, and may vary between regions, with possible prognostic implications, for example, PTEN loss is uncommon in NRAS-mutant melanoma but occurs in BRAF-mutant melanoma and can activate the PI3K pathway (Hodis et al, 2012). Although NRAS mutations cause both PI3K/AKT and MAPK pathway activation (Tsao et al, 2000), it remains to be determined if activation of the PI3K pathway is prognostic in melanoma. This dual pathway activation is one hypothesis to explain the association between NRAS mutations and a poorer prognosis compared with BRAF mutations in the previous studies of melanoma (Jakob et al, 2012). However, this is not the case in colorectal cancer where BRAF mutations carry a poorer prognosis compared with KRAS mutant disease (Van Cutsem et al, 2011; Yokota et al, 2011; Toland et al, 2012). A meta-analysis may help to clarify the effect of mutation status on survival.
We found no differences in the clinicopathologic factors of the antecedent primary melanoma based on the mutation status, similar to prior studies (Shinozaki et al, 2004; Edlundh-Rose et al, 2006), but in contrast to one study which reported association between BRAF positivity and thinner primaries with lower numbers of mitoses (Devitt et al, 2011b).

There was no association between the patterns of organ involvement of metastatic disease both at the time of distant metastasis (stage IV) diagnosis and BRAF/NRAS mutation status, although we found non-lung visceral metastases (M1c disease) more common in patients with NRAS-mutant disease. One previous study reported an association between $B R A F$ or NRAS mutations and the presence of CNS metastases at first occurrence of stage IV disease (Jakob et al, 2012). Our data show a trend towards higher rates of brain metastasis at initial stage IV diagnosis in keeping with this, but we show for the first time that the risk of developing brain metastasis at any time is comparable at $40-45 \%$ of patients irrespective of $B R A F / N R A S$ mutation status.

The response to chemotherapy was not influenced by mutation status. Although BRAF wild-type melanomas have been reported to have a higher response rate to regional chemotherapy (Gallagher et al, 2008), in keeping with our data, mutation status did not influence response or survival to systemic therapy with nab-paclitaxel or dacarbazine (Hersh et al, 2013). Exploratory 

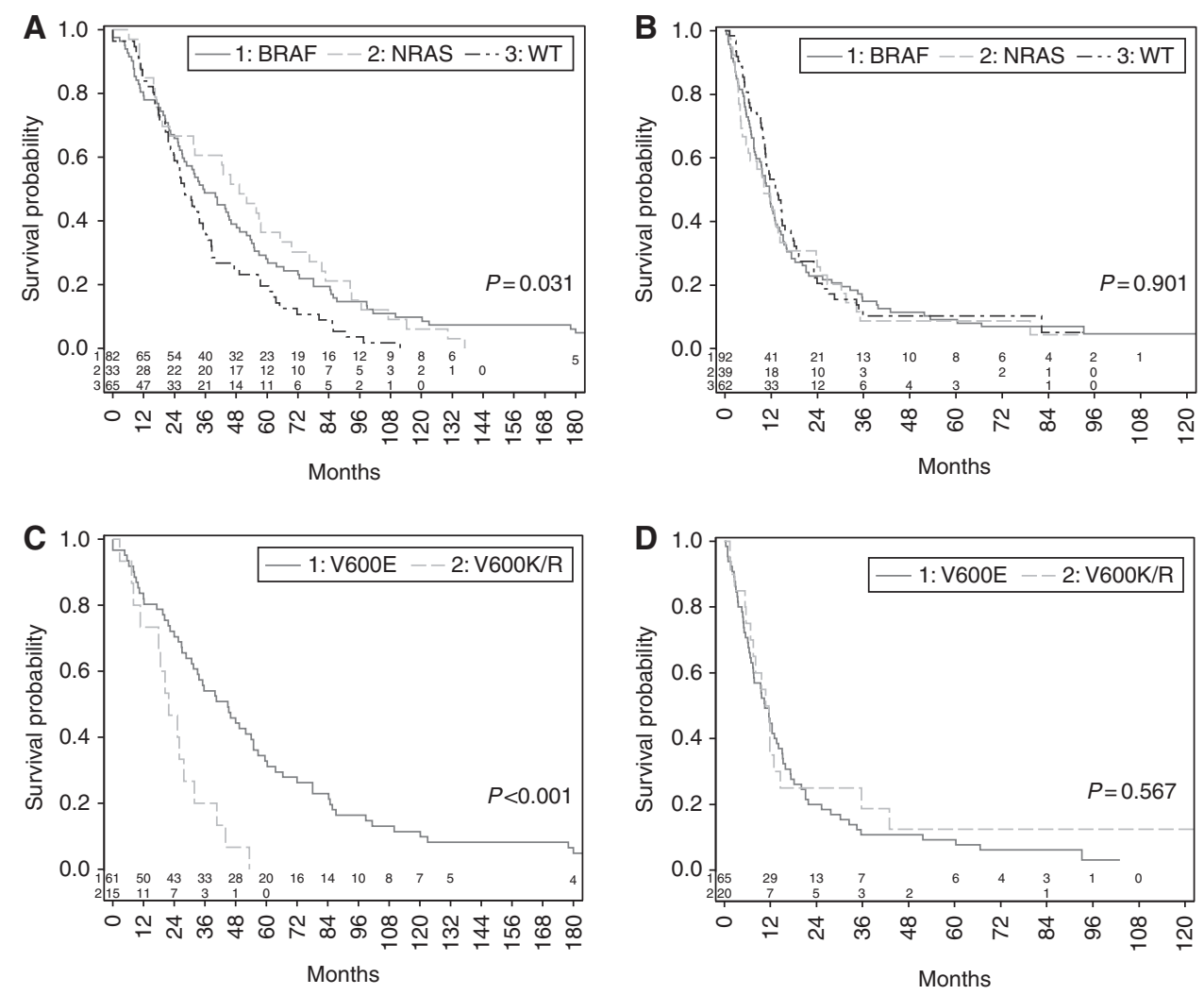

Figure 1. Impact of mutation status on DDFI and survival from stage IV melanoma. (A) DDFI from culprit primary melanoma based on BRAF and NRAS status. (B) Survival from diagnosis of stage IV melanoma based on BRAF and NRAS mutation status. (C) DDFI from culprit primary melanoma based on BRAF mutation genotype. (D) Survival from diagnosis of stage IV melanoma based on BRAF mutation genotype.

\begin{tabular}{|c|c|c|c|c|c|}
\hline \multirow[b]{2}{*}{ Factor } & \multirow[b]{2}{*}{ Value } & \multicolumn{3}{|c|}{$\begin{array}{c}95 \% \text { Confidence } \\
\text { interval }\end{array}$} & \multirow[b]{2}{*}{$P$-value } \\
\hline & & $\begin{array}{c}\text { Hazard } \\
\text { ratio }\end{array}$ & Lower & Upper & \\
\hline \multirow{4}{*}{ Breslow thickness groups } & $\mathrm{T} 1$ & \multicolumn{4}{|c|}{ Reference } \\
\hline & $\mathrm{T} 2$ & 1.225 & 0.750 & 2.000 & 0.417 \\
\hline & T3 & 1.443 & 0.918 & 2.270 & 0.112 \\
\hline & T4 & 3.013 & 1.811 & 5.012 & $<0.001$ \\
\hline \multirow{6}{*}{$\mathrm{N}$ stage } & No & \multicolumn{4}{|c|}{ Reference } \\
\hline & $\mathrm{N} 1 \mathrm{a}$ & 1.952 & 1.172 & 3.252 & 0.010 \\
\hline & $\mathrm{N} 1 \mathrm{~b}$ & 14.494 & 1.755 & 119.661 & 0.013 \\
\hline & N2a & 1.566 & 0.853 & 2.875 & 0.148 \\
\hline & $\mathrm{N} 2 \mathrm{~b}$ & 0.614 & 0.144 & 2.614 & 0.509 \\
\hline & N3 & 2.680 & 1.119 & 6.420 & 0.027 \\
\hline \multirow{3}{*}{ Mutation } & WT & \multicolumn{4}{|c|}{ Reference } \\
\hline & NRAS & 0.679 & 0.429 & 1.073 & 0.097 \\
\hline & BRAF & 0.715 & 0.489 & 1.045 & 0.083 \\
\hline
\end{tabular}

analysis have found an association between BRAF wild-type tumours and response to an investigational combination including the anti-angiogenic therapy bevacizumab (von Moos et al, 2011), NRAS mutations have also been reported to be associated with an improved response to immunotherapy as compared with patients having BRAF/NRAS wild-type tumours (Johnson et al, 2013). Analysis as part of future clinical trials should determine if mutation status is predictive in treatments beyond those involving inhibitors of the MAPK pathway.

\begin{tabular}{|c|c|c|c|c|c|}
\hline \multirow[b]{2}{*}{ Factor } & \multirow[b]{2}{*}{ Value } & \multicolumn{3}{|c|}{\begin{tabular}{|c|}
$95 \%$ Confidence \\
interval
\end{tabular}} & \multirow[b]{2}{*}{$P$-value } \\
\hline & & $\begin{array}{c}\text { Hazard } \\
\text { ratio }\end{array}$ & Lower & Upper & \\
\hline \multirow{4}{*}{ Breslow thickness groups } & $\mathrm{T} 1$ & \multicolumn{4}{|c|}{ Reference } \\
\hline & $\mathrm{T} 2$ & 1.350 & 0.657 & 2.774 & 0.414 \\
\hline & T3 & 2.054 & 0.998 & 4.229 & 0.051 \\
\hline & T4 & 4.575 & 1.990 & 10.518 & $<0.001$ \\
\hline \multirow{4}{*}{$\mathrm{N}$ stage } & No & \multicolumn{4}{|c|}{ Reference } \\
\hline & N1 & 3.887 & 1.773 & 8.522 & 0.001 \\
\hline & N2 & 3.434 & 1.493 & 7.897 & 0.004 \\
\hline & N3 & 1.238 & 0.387 & 3.958 & 0.719 \\
\hline \multirow{2}{*}{ Mutation } & V600E & \multicolumn{4}{|c|}{ Reference } \\
\hline & $\mathrm{V} 600 \mathrm{~K} / \mathrm{R}$ & 2.248 & 1.112 & 4.543 & 0.024 \\
\hline
\end{tabular}

Our finding that tumours with a $B R A \mathrm{~F}^{\mathrm{V} 600 \mathrm{~K} / \mathrm{R}}$ mutation have a significantly shorter DDFI than those with the more common $\mathrm{BRAF}^{\mathrm{V} 600 \mathrm{E}}$ mutation confirms prior reports (Menzies et al, 2012; Bucheit et al, 2013). We found no impact of BRAF mutation genotype on OS from the time of first diagnosis of stage IV melanoma, as previously reported in a different cohort from our institution (Menzies et al, 2012), although another study found V600K mutations were associated with a poorer survival from stage IV (Bucheit et al, 2013). Analysis of DDFI and survival from stage IV diagnosis based on exon 1 or 2 NRAS mutations showed no significant difference based on genotype, in keeping with prior 
studies (Bucheit et al, 2013). Nevertheless, this exploratory analysis is limited by the relatively small number of patients with NRAS mutations in this cohort.

In conclusion, our data show that BRAF and NRAS mutations are not prognostic in advanced melanoma. We confirmed the association between the $B R A F^{\mathrm{V} 600 \mathrm{~K} / \mathrm{R}}$ genotype and a shorter DDFI compared with $B R A F^{\mathrm{V} 600 \mathrm{E}}$ in an independent cohort, but there was no difference in survival from stage IV diagnosis. Given the activity of BRAF and MEK inhibitors, future studies examining the prognostic impact of $B R A F$ mutation status in advanced melanoma will be difficult to interpret and future studies should examine other genetic factors which may explain the conflicting results seen across multiple studies.

\section{ACKNOWLEDGEMENTS}

This work was supported by Program Grant 633004 and project grants of the National Health and Medical Research Council of Australia (NHMRC), and an educational grant from Roche Products, Pty Limited (Australia). RA Scolyer, GV Long and SA O'Toole are recipients of Cancer Institute New South Wales, Research Fellowships and RA Scolyer is supported by an NHMRC Practitioner Fellowship. MS Carlino is supported by a Rotary Health Australia scholarship. WA Cooper is supported by Sydney Foundation for Medical Research.

\section{CONFLICT OF INTEREST}

Carlino MS received honoraria from Novartis, Roche, GlaxoSmithKline and Bristol-Myers Squibb. Menzies AM received travel support from Roche and GlaxoSmithKline, and honoraria from Roche. Hamilton AL received travel support from Roche. Cooper WA received consultancies and honararia from Pfizer and Merck. O’Toole S received honoraria from Roche, Astra Zeneca and Pfizer. Thompson JF received consultancies and honoraria from Roche and GlaxoSmithKline. Kefford RF received consultancies and honoraria from Roche, GlaxoSmithKline and Novartis. Scolyer RA received consultancies from Roche and GlaxoSmithKline, honoraria from Abbott Molecular. Long GV received consultancies from Roche, Bristol-Myers Squibb, GlaxoSmithKline, Novartis and Amgen; honoraria from Roche; travel support from GlaxoSmithKline and Roche Melanoma Institute Australia received research support from Roche. The remaining authors declare no conflict of interest.

\section{REFERENCES}

Akslen LA, Angelini S, Straume O, Bachmann IM, Molven A, Hemminki K, Kumar R (2005) BRAF and NRAS mutations are frequent in nodular melanoma but are not associated with tumor cell proliferation or patient survival. J Invest Dermatol 125(2): 312-317.

Amanuel B, Grieu F, Kular J, Millward M, Iacopetta B (2012) Incidence of BRAF p.Val600Glu and p.Val600Lys mutations in a consecutive series of 183 metastatic melanoma patients from a high incidence region. Pathology 44(4): 357-359.

Ascierto PA, Schadendorf D, Berking C, Agarwala SS, van Herpen CM, Queirolo P, Blank CU, Hauschild A, Beck JT, St-Pierre A, Niazi F, Wandel S, Peters M, Zubel A, Dummer R (2013) MEK162 for patients with advanced melanoma harbouring NRAS or Val600 BRAF mutations: a non-randomised, open-label phase 2 study. Lancet Oncol 14(3): 249-256.

Brissy S, Gaudy-Marqueste C, Mallet S, Monestier S, Hesse S, Koeppel M-C, Rojat-Habib M-C, Nanni I, Loundou A, Lh Ouafik, Bonnet N, Richard M-A, Grob JJ (2012) BRAF mutation as a pejorative marker in metastatic melanoma. J Clin Oncol 30(suppl): abstr 8555.
Bucheit AD, Syklawer E, Jakob JA, Bassett Jr RL, Curry JL, Gershenwald JE, Kim KB, Hwu P, Lazar AJ, Davies MA (2013) Clinical characteristics and outcomes with specific BRAF and NRAS mutations in patients with metastatic melanoma. Cancer 119(21): 3821-3829.

Chang DZ, Panageas KS, Osman I, Polsky D, Busam K, Chapman PB (2004) Clinical significance of BRAF mutations in metastatic melanoma. J Transl Med 2(1): 46.

Chapman PB, Hauschild A, Robert C, Haanen JB, Ascierto P, Larkin J, Dummer R, Garbe C, Testori A, Maio M, Hogg D, Lorigan P, Lebbe C, Jouary T, Schadendorf D, Ribas A, O'Day SJ, Sosman JA, Kirkwood JM, Eggermont AMM, Dreno B, Nolop K, Li J, Nelson B, Hou J, Lee RJ, Flaherty KT, McArthur AG (2011) Improved survival with vemurafenib in melanoma with BRAF V600E mutation. $N$ Engl J Med 364(26): 2507-2516.

Davies H, Bignell GR, Cox C, Stephens P, Edkins S, Clegg S, Teague J, Woffendin H, Garnett MJ, Bottomley W, Davis N, Dicks E, Ewing R, Floyd Y, Gray K, Hall S, Hawes R, Hughes J, Kosmidou V, Menzies A, Mould C, Parker A, Stevens C, Watt S, Hooper S, Wilson R, Jayatilake H, Gusterson BA, Cooper C, Shipley J, Hargrave D, Pritchard-Jones K, Maitland N, Chenevix-Trench G, Riggins GJ, Bigner DD, Palmieri G, Cossu A, Flanagan A, Nicholson A, Ho JW, Leung SY, Yuen ST, Weber BL, Seigler HF, Darrow TL, Paterson H, Marais R, Marshall CJ, Wooster R, Stratton MR, Futreal PA (2002) Mutations of the BRAF gene in human cancer. Nature 417(6892): 949-954.

Devitt B, Liu W, Salemi R, Wolfe R, Kelly J, Tzen C-Y, Dobrovic A, McArthur G (2011a) Clinical outcome and pathological features associated with NRAS mutation in cutaneous melanoma. Pigment Cell Melanoma Res 24(4): 666-672.

Devitt B, Liu W, Salemi R, Wolfe R, Kelly J, Tzen CY, Dobrovic A, McArthur G (2011b) Clinical outcome and pathological features associated with NRAS mutation in cutaneous melanoma. Pigment Cell Melanoma Res 24(4): 666-672.

Edlundh-Rose E, Egyhazi S, Omholt K, Mansson-Brahme E, Platz A, Hansson J, Lundeberg J (2006) NRAS and BRAF mutations in melanoma tumours in relation to clinical characteristics: a study based on mutation screening by pyrosequencing. Melanoma Res 16(6): 471-478.

Ekedahl H, Cirenajwis H, Harbst K, Carneiro A, Nielsen K, Olsson H, Lundgren L, Ingvar C, Jonsson G (2013) The clinical significance of BRAF and NRAS mutations in a clinic-based metastatic melanoma cohort. Br J Dermatol 169(5): 1049-1055.

Elisei R, Viola D, Torregrossa L, Giannini R, Romei C, Ugolini C, Molinaro E, Agate L, Biagini A, Lupi C, Valerio L, Materazzi G, Miccoli P, Piaggi P, Pinchera A, Vitti P, Basolo F (2012) The BRAF(V600E) mutation is an independent, poor prognostic factor for the outcome of patients with low-risk intrathyroid papillary thyroid carcinoma: single-institution results from a large cohort study. J Clin Endocrinol Metab 97(12): 4390-4398.

Falchook GS, Lewis KD, Infante JR, Gordon MS, Vogelzang NJ, DeMarini DJ, Sun P, Moy C, Szabo SA, Roadcap LT, Peddareddigari VG, Lebowitz PF, Le NT, Burris 3rd HA, Messersmith WA, O'Dwyer PJ, Kim KB, Flaherty K, Bendell JC, Gonzalez R, Kurzrock R, Fecher LA (2012) Activity of the oral MEK inhibitor trametinib in patients with advanced melanoma: a phase 1 dose-escalation trial. Lancet Oncol 13(8): 782-789.

Fernandez IJ, Piccin O, Sciascia S, Cavicchi O, Repaci A, Vicennati V, Fiorentino M (2013) Clinical significance of BRAF mutation in thyroid papillary cancer. Otolaryngol Head Neck Surg 148(6): 919-925.

Flaherty KT, Robert C, Hersey P, Nathan P, Garbe C, Milhem M, Demidov LV, Hassel JC, Rutkowski P, Mohr P, Dummer R, Trefzer U, Larkin JMG, Utikal J, Dreno B, Nyakas M, Middleton MR, Becker JC, Casey M, Sherman LJ, Wu FS, Ouellet D, Martin A-M, Patel K, Schadendorf D (2012) Improved survival with MEK inhibition in BRAF-mutated melanoma. N Engl J Med 367(2): 107-114.

Gallagher SJ, Thompson JF, Indsto J, Scurr LL, Lett M, Gao BF, Dunleavey R, Mann GJ, Kefford RF, Rizos H, Gallagher SJ, Thompson JF, Indsto J, Scurr LL, Lett M, Gao B-F, Dunleavey R, Mann GJ, Kefford RF, Rizos H (2008) p16INK4a expression and absence of activated B-RAF are independent predictors of chemosensitivity in melanoma tumors. Neoplasia 10(11): 1231-1239.

Greaves WO, Verma S, Patel KP, Davies MA, Barkoh BA, Galbincea JM, Yao H, Lazar A, Aldape KD, Medeiros LJ, Luthra R (2012) Frequency and spectrum of BRAF mutations in a retrospective, single-institution study of 1112 cases of melanoma. J Mol Diagn 26(12): 00310-00318.

Hauschild A, Grob J-J, Demidov LV, Jouary T, Gutzmer R, Millward M, Rutkowski P, Blank CU, Miller WH, Kaempgen E, Martín-Algarra S, 
Karaszewska B, Mauch C, Chiarion-Sileni V, Martin A-M, Swann S, Haney P, Mirakhur B, Guckert ME, Goodman V, Chapman PB (2012) Dabrafenib in BRAF-mutated metastatic melanoma: a multicentre, open-label, phase 3 randomised controlled trial. Lancet 380(9839): 358-365.

Hersh E, Del Vecchio M, Brown MP, Kefford R, Loquai C, Testori A, Robert C, Li M, Elias I, Renschler MF, Hauschild A (2013) A phase III tria of nab-paclitaxel versus dacarbazine in chemotherapy-naive patients with metastatic melanoma: a subanalysis based on BRAF status. J Clin Oncol 31(suppl): abstr 9030.

Hodis E, Watson Ian R, Kryukov Gregory V, Arold Stefan T, Imielinski M, Theurillat J-P, Nickerson E, Auclair D, Li L, Place C, DiCara D, Ramos Alex H, Lawrence Michael S, Cibulskis K, Sivachenko A, Voet D, Saksena G, Stransky N, Onofrio Robert C, Winckler W, Ardlie K, Wagle N, Wargo J, Chong K, Morton Donald L, Stemke-Hale K, Chen G, Noble M, Meyerson M, Ladbury John E, Davies Michael A, Gershenwald Jeffrey E, Wagner Stephan N, Hoon Dave SB, Schadendorf D, Lander Eric S, Gabriel Stacey B, Getz G, Garraway Levi A, Chin L (2012) A landscape of driver mutations in melanoma. Cell 150(2): 251-263.

Houben R, Becker JC, Kappel A, Terheyden P, Brocker EB, Goetz R, Rapp UR (2004) Constitutive activation of the Ras-Raf signaling pathway in metastatic melanoma is associated with poor prognosis. J Carcinog 3(1): 6 .

Jakob JA, Bassett Jr RL, Ng CS, Curry JL, Joseph RW, Alvarado GC, Rohlfs ML, Richard J, Gershenwald JE, Kim KB, Lazar AJ, Hwu P, Davies MA (2012) NRAS mutation status is an independent prognostic factor in metastatic melanoma. Cancer 118(16): 4014-4023.

Johnson DB, Lovly CM, Flavin M, Ayers GD, Zhao Z, Iams WT, Iafrate AJ, Berry EG, Terry CR, Sullivan RJ, Carvajal RD, Sosman JA. (2013) NRAS mutation: A potential biomarker of clinical response to immune-based therapies in metastatic melanoma (MM). J Clin Oncol 31(suppl): abstr 9019 .

Long GV, Menzies AM, Nagrial AM, Haydu LE, Hamilton AL, Mann GJ, Hughes TM, Thompson JF, Scolyer RA, Kefford RF (2011) Prognostic and clinicopathologic associations of oncogenic BRAF in metastatic melanoma. J Clin Oncol 29(10): 1239-1246.

Maldonado JL, Fridlyand J, Patel H, Jain AN, Busam K, Kageshita T, Ono T, Albertson DG, Pinkel D, Bastian BC (2003) Determinants of BRAF mutations in primary melanomas. J Natl Cancer Inst 95(24): 1878-1890.

Mann GJ, Pupo GM, Campain AE, Carter CD, Schramm SJ, Pianova S, Gerega SK, De Silva C, Lai K, Wilmott JS, Synnott M, Hersey P, Kefford RF, Thompson JF, Yang YH, Scolyer RA (2013) BRAF mutation, NRAS mutation, and the absence of an immune-related expressed gene profile predict poor outcome in patients with stage III melanoma. J Invest Dermatol 133(2): 509-517.

Menzies AM, Haydu LE, Visintin L, Carlino MS, Howle JR, Thompson JF, Kefford RF, Scolyer RA, Long GV (2012) Distinguishing clinicopathologic features of patients with V600E and V600K BRAF-mutant metastatic melanoma. Clin Cancer Res 18(12): 3242-3249.

Moreau S, Saiag P, Aegerter P, Bosset D, Longvert C, Helias-Rodzewicz Z, Marin C, Peschaud F, Chagnon S, Zimmermann U, Clerici T, Emile JF (2012) Prognostic value of $\operatorname{BRAF}(\mathrm{V}(6)(0)(0))$ mutations in melanoma patients after resection of metastatic lymph nodes. Ann Surg Oncol 19(13): 4314-4321.

Murali R, Brown PT, Kefford RF, Scolyer RA, Thompson JF, Atkins MB, Long GV (2012) Number of primary melanomas is an independent predictor of survival in patients with metastatic melanoma. Cancer 118(18): 4519-4529.

Nagore E, Hacker E, Martorell-Calatayud A, Traves V, Guillen C, Hayward NK, Whiteman D (2013) Prevalence of BRAF and NRAS mutations in fast-growing melanomas. Pigment Cell Melanoma Res 26(3): 429-431.

Platz A, Egyhazi S, Ringborg U, Hansson J (2008) Human cutaneous melanoma; a review of NRAS and BRAF mutation frequencies in relation to histogenetic subclass and body site. Mol Oncol 1(4): 395-405.

Prescott JD, Sadow PM, Hodin RA, Le LP, Gaz RD, Randolph GW, Stephen AE, Parangi S, Daniels GH, Lubitz CC (2012) BRAF V600E status adds incremental value to current risk classification systems in predicting papillary thyroid carcinoma recurrence. Surgery 152(6): 984-990.

Rutkowski P, Jurkowska M, Gos A, Tysarowski A, Michej W, Switaj T, Dziewirski W, Zdzienicki M, Falkowski S, Olszewski WT, Siedlecki JA (2012) Correlations of molecular alterations in clinical stage III cutaneous melanoma with clinical-pathological features and patients outcome. J Clin Oncol 30(suppl): abstr 8548.

Shinozaki M, Fujimoto A, Morton DL, Hoon DS (2004) Incidence of BRAF oncogene mutation and clinical relevance for primary cutaneous melanomas. Clin Cancer Res 10(5): 1753-1757.

Toland AE, Safaee Ardekani G, Jafarnejad SM, Tan L, Saeedi A, Li G (2012) The prognostic value of BRAF mutation in colorectal cancer and melanoma: a systematic review and meta-analysis. PLoS One 7(10): e47054.

Tsao H, Zhang X, Fowlkes K, Haluska FG (2000) Relative reciprocity of NRAS and PTEN/MMAC1 alterations in cutaneous melanoma cell lines. Cancer Res 60(7): 1800-1804.

Ugurel S, Thirumaran RK, Bloethner S, Gast A, Sucker A, Mueller-Berghaus J, Rittgen W, Hemminki K, Becker JC, Kumar R, Schadendorf D (2007) B-RAF and N-RAS mutations are preserved during short time in vitro propagation and differentially impact prognosis. PLoS One 2(2): e236.

Van Cutsem E, Kohne CH, Lang I, Folprecht G, Nowacki MP, Cascinu S, Shchepotin I, Maurel J, Cunningham D, Tejpar S, Schlichting M, Zubel A, Celik I, Rougier P, Ciardiello F (2011) Cetuximab plus irinotecan, fluorouracil, and leucovorin as first-line treatment for metastatic colorectal cancer: updated analysis of overall survival according to tumor KRAS and BRAF mutation status. J Clin Oncol 29(15): 2011-2019.

von Moos R, Seifert B, Simcock M, Goldinger SM, Gillessen S, Ochsenbein A, Michielin O, Cathomas R, Schlappi M, Moch H, Schraml PH, Mjhic-Probst D, Mamot C, Schonewolf N, Dummer R (2011) First-line temozolomide combined with bevacizumab in metastatic melanoma: a multicentre phase II trial (SAKK 50/07). Ann Oncol 23(2): 531-536.

Yokota T, Ura T, Shibata N, Takahari D, Shitara K, Nomura M, Kondo C, Mizota A, Utsunomiya S, Muro K, Yatabe Y (2011) BRAF mutation is a powerful prognostic factor in advanced and recurrent colorectal cancer. Br J Cancer 104(5): 856-862.

This work is published under the standard license to publish agreement. After 12 months the work will become freely available and the license terms will switch to a Creative Commons AttributionNonCommercial-Share Alike 3.0 Unported License.

Supplementary Information accompanies this paper on British Journal of Cancer website (http://www.nature.com/bjc) 